\title{
A review of the present position of Australia antigen
}

\author{
F. O. MacCallum \\ Department of Pathology, Radcliffe Infirmary, Oxford
}

\begin{abstract}
Summary
The nature of Australian antigen, its site of replication and its probable nature are discussed.

The influence of genetic factors in the incidence of hepatitis associated with Australia antigen or its carriage is reviewed.
\end{abstract}

\section{Characteristics of the virus}

A brief review of the present position of $\mathrm{Au}$ antigen logically begins with consideration of what the term embraces. At the present moment the antigen is considered to be present in three forms and sizes, measured in the electron microscope on negatively stained preparations of serum. There is the first form described (Bayer, Blumberg \& Werner, 1968) about $20 \mathrm{~nm}$ or $200 \AA$ in diameter, which is also the commonest in most sera. It is pleomorphic with a tendency to be spherical. The next larger form, the so-called Dane particles (Dane, Cameron \& Briggs, 1970) are $40-45 \mathrm{~nm}$ in diameter, many are five- or six-sided and double-shelled. These are usually less in number although they may predominate in certain situations. Lastly there are the tubular forms about $20 \mathrm{~nm}$ in diameter but of varying length - the first form may be found by itself but the second two rarely, if ever. We have seen a preponderance of large forms in some sera from males with Down's syndrome, who have been healthy carriers for several years. The centre of controversy at present is which is the important particle. Dr Dane suggested that the $40 \mathrm{~nm}$ particle is the mature virion or capsid. He suggested that the smaller particles are virus coat material or degradation products as they are less regular in size and less dense than known viruses of similar size, and that there are usually many more present than are necessary in relation to the infectivity of the serum. Figures such as $10^{11}-10^{13} / \mathrm{ml}$ have been estimated by various workers. Cossart \& Field (1970) and some other workers postulated that the large particles are simply an in vitro aggregation of smaller particles and Zuckerman, Taylor \& Bird, (1970) have hinted that the large forms might be coiled tubules. All sizes of particles aggregate together when mixed with human antisera to the Australia antigen suggesting that they share a common antigen. I know of no reports of inoculation of purified preparations into humans so it is not known whether one or allor none-are the disease-producing particle. The fact that no nucleic acid has been detected in any preparations underlines another difficulty in accepting them as a virus although a similar situation applies to some of the so-called 'slow' viruses.

Experiments in volunteers and subsequently on Australia antigen-containing sera have shown that the methods used for inactivating most viruses, e.g. heating at $56^{\circ} \mathrm{C}$ for $18 \mathrm{hr}$ or $60^{\circ} \mathrm{C}$ for $1 \mathrm{hr}$, and treatment with $10 \%$ ether for $18 \mathrm{hr}$ at $4^{\circ} \mathrm{C}$ or $1 \%$ sodium desoxycholate on these with lipoprotein, do not destroy the stability of the complement-fixing antigen or reduce the infectivity of the serum. The stability of the small forms at temperatures of $4^{\circ} \mathrm{C}$ or lower was seen in a preparation of serum from a carrier, G, which was frozen and thawed at various temperatures between 1951 when it was icterogenic in volunteers, and 1969 when it was found to be positive for Au antigen. A serum collected in 1969 from the same patient, who had been symptomless in the meantime, and had normal liver function tests, was shown to contain the same forms by Zuckerman \& Taylor (1969).

The next and probably most important problem is the site of replication of the agent in man and the excretions or secretions of the body which may be a source of infection in addition to the blood. The antigen has been reported visualized by electron microscopy and immunofluorescence in the liver by several investigators (Nowoslawski et al., 1970) and Mrs Almeida will be discussing this subject. Australia antigen has not been demonstrated conclusively in any material other than blood (or possibly liver) and although the blood has been infective by the oral route in one group of children (Krugman, Giles \& Hammond, 1967; Giles et al., 1969) and there is an accumulation of evidence indicating that transmission may occur by mechanisms other than obvious injection of blood there is no proof of how this occurs. Australia antigen is thus only associated with the causation of so-called serum hepatitis and is by inference probably synonymous with hepatitis virus B (MacCallum, 1947) and Krugman's MS2 agent (Krugman et al., 1967). It is not associated with virus A or MS1, which are representative of agents causing epidemic infectious hepatitis by the faecal/oral route although a person infected with this may be a carrier of virus B (MacCallum, 1953) or Australia antigen. There may be several antigenic types of these agents or even different viruses. Virus B may have been derived from A as a result of parenteral passage (MacCallum, 1953). The figures 
TABLE 1. U.K. serum pools

\begin{tabular}{|c|c|c|c|c|c|}
\hline & $\begin{array}{l}\text { Number } \\
\text { inoculated }\end{array}$ & Route & Jaundice & $\begin{array}{c}\text { Interval } \\
\text { (days) }\end{array}$ & Au antigen \\
\hline 034 & 18 & $\begin{array}{l}1.0 \mathrm{ml} \\
\text { subcut. }\end{array}$ & 9 & $60-114$ & $\begin{array}{c}+ \text { in E.M. } \\
\text { only }\end{array}$ \\
\hline Ether treated & 19 & $\begin{array}{l}1.0 \mathrm{ml} \\
\text { subcut. }\end{array}$ & 10 & $83-131$ & \\
\hline $207 \mathrm{KY}$ & 11 & $\begin{array}{l}1.0 \mathrm{ml} \\
\text { subcut. }\end{array}$ & 4 & $59-135$ & $\begin{array}{c}\text { - by all } \\
\text { tests }\end{array}$ \\
\hline YF vaccine & $\begin{array}{c}125 \\
\text { on one day }\end{array}$ & $\begin{array}{l}\text { '0.1 ml' } \\
\text { subcut. }\end{array}$ & 46 & $73-99$ & \\
\hline
\end{tabular}

in Table 1 show that the two original icterogenic pools, 034 (Bradley, Loutit \& Maunsell, 1944; MacCallum, 1946) and 207KY (MacCallum \& Bauer, 1944) which were investigated in the U.K. in 1939-45 had similar incubation periods and attack rates. Particles resembling all three forms of Australia antigen are visible, although in small amounts, in electronmicrographs of 034 prepared for me by Mrs Almeida but she and we have failed to find any such particles in the last surviving ampoule of $207 \mathrm{KY}$ and no antigen or antibody could be detected in either serum by agar gel diffusion complement-fixation, or immunoelectrophoresis.

The final specific point on identification of the Australia antigen and its relation to infection is that although an antibody (or antibodies) to it has been found in human sera, neither this nor the gammaglobulin made from either blood of volunteers convalescent from virus B infection (Drake et al., 1953) or large pools of human serum reduce the incidence of virus B or Australia antigen-associated hepatitis (Co-operative Study, 1970).

\section{Influence of genetic factors}

Next I shall consider briefly the possible influence of genetic factors such as blood groups or Down's syndrome or immunological defects as may be found in leukaemia, on disease or symptomless carriage of Australia antigen. Blumberg, Sutnick \& Loudon (1969) suggested that there is a host susceptibility to persistent antigen carriage and that this is controlled by an autosomal recessive gene. Table 2 shows the relative proportion of the important blood groups in the Liverpool dialysis unit hepatitis patients as reported by Lewkonia \& Finn in 1969. The excess of group 0 in those with hepatitis compared with controls is obvious and it is disappointing that others have not reported on this topic from other dialysis units affected by hepatitis. Doctor Ringertz of Stockholm and Professor Marmion of Edinburgh kindly provided me with data which are less comprehensive than that from Liverpool but no excess of group 0 was present.

The finding of Australia antigen in a high proportion of Down's syndrome patients in institutions
TABLE 2. ABO blood group distribution in renal dialysis unit, Liverpool to August 1969

\begin{tabular}{lccc}
\hline & \multicolumn{3}{c}{ Blood Group } \\
\cline { 2 - 4 } & O & & Non-O \\
\hline Hepatitis & 29 & & 16 \\
No hepatitis & 16 & & 35 \\
$\quad$ Total at risk & 7 & 96 & 3 \\
Hepatitis & 1 & & 7 \\
$\quad$ No hepatitis & \multicolumn{2}{c}{18} & \\
\hline Dialysis patients at risk & \multicolumn{3}{c}{} \\
\hline
\end{tabular}

(Blumberg et al., 1967) was a landmark in the development of this subject for attention had been drawn to the frequency with which hepatitis mayo occur in these patients under these conditions and this led to the study of hepatitis by Blumberg and hiso colleagues. In 1962, at a time when new candidate hepatitis viruses had been reported from the U.S.A. and we had obtained material for study an outbreak of hepatitis occurred in patients and staff of an institution for the mentally retarded in Buckinghamshire, and Dr H. O. Phillipson, who was in charge of the patients, sent me serum from thirty-nine of the fifty-six patients who had hepatitis in a total population of 164. These sera were used in various tests which did not help in the solution of the problem and the sera were stored at $-30^{\circ} \mathrm{C}$. In Table 3 the first line shows the results when these sera were tested for Australia antigen in 1969. The four positives were all boys with Down's syndrome. We then collected blood from most of the inmate population -110 . In the second line are the results on those who has been tested in 1962 and found negative; only one of twenty-one had converted and remained positive. We do not know whether any had been positive and the antigen had disappeared. In the third line are the total results in 1969/70. The second striking feature is the absence of positives in the girls. The positives in the boys were confined to patients in two houses. It is not possible to say whether introduction of the antigen occurred before or after admission except on the one boy who converted, nor how he became a carrier. All the positives are, of course, symptomless carriers. Tests 
TABLE 3. HAA in Down's syndrome (DS) and other mentally retarded children (OMR)

\begin{tabular}{|c|c|c|c|c|}
\hline & \multicolumn{2}{|c|}{ Male } & \multicolumn{2}{|c|}{ Female } \\
\hline & DS & OMR & DS & OMR \\
\hline 1962 & $4 / 8 * \dagger$ & $\begin{array}{l}0 / 15 \\
\text { (Total c }\end{array}$ & $\begin{array}{c}0 / 7 \\
\text { on } 164)\end{array}$ & $0 / 9$ \\
\hline $\begin{array}{l}\text { Negative survivors } \\
\text { tested } 1969 \\
\text { Total } 1969\end{array}$ & $\begin{array}{c}0 / 3 \\
8 / 20^{*} \ddagger\end{array}$ & $\begin{array}{l}1 / 7 \\
3 / 30 \S\end{array}$ & $\begin{array}{c}0 / 4 \\
0 / 23\end{array}$ & $\begin{array}{c}0 / 7 \\
0 / 37\end{array}$ \\
\hline
\end{tabular}

on sera obtained from twenty-eight Down's syndrome patients in another institution, with the collaboration of Dr A. C. Coombes were negative for Australia antigen. We have examined sera from only three patients with Down's syndrome shortly after birth and these were negative; a similar result to that reported by others for larger numbers of patients with this condition not in institutions.

In their earlier studies Blumberg and his colleagues found a high rate of $\mathrm{Au}$ positive sera in patients with chronic lymphatic leukaemia (Blumberg, Alter \& Visnich, 1965; Blumberg et al., 1967), and at one time (Blumberg et al., 1965) they even suggested that it might be used as a test for leukaemia. In subsequent studies carriage of the antigen was found to be directly related to blood transfusion, as one might expect. I have tested sera collected in the past three years from thirty-one patients with chronic lymphatic leukaemia, twenty-one with Hodgkin's disease and twenty-two from other forms of leukaemia and a variety of reticuloses including disseminated lupus erythematosus, a total of seventy-four (most of whom have been under the care of Dr Sheila Callender); several patients have been tested two or more times at intervals and none of these has been positive for $\mathrm{Au}$ antigen in the double diffusion in agar gel test. This result is not unexpected as the rate for donors in the Oxford region at the present time appears to be less than one in 600 . In other words if chronic lymphatic leukaemia patients are transfused with blood containing Au antigen they may become carriers due to immunological defects but whether they become so depends on the source of the blood with which they are transfused.

In conclusion, much further knowledge of Australia antigen will be limited until some means of studying its replication in the laboratory is found.

\section{References}

BAyer, M.E., Blumberg, B.S. \& Werner, B. (1968) Particles associated with Australia antigen in sera of patients with leukaemia, Down's syndrome and hepatitis. Nature, 218, 1057.

Blumberg, B.S., Alter, H.J. \& Visnich, S. (1965) A 'new' antigen in leukaemia sera. Journal of the American Medical Association, 191, 541.

Blumberg, B.S., Gerstley, B.J., Hungerford, D.A., London, W.T. \& SutNick, A.I. (1967) A serum antigen (Australia antigen) in Down's syndrome, leukaemia and hepatitis. Annals of Internal Medicine, 66, 924.

Blumberg, B.S., Sutnick, A.I. \& London, W.T. (1969) Australia antigen and hepatitis. Journal of the American Medical Association, 207, 1895.

Bradley, W.H., Loutit, J.F. \& Maunsell, K. (1944) An episode of 'Homologous serum jaundice'. British Medical Journal, 2, 268.

Co-OPERATIVE STUdY (1970) Non-prevention of posttransfusion hepatitis by gammaglobulin. Journal of the American Medical Association, 214, 140.

COSSART, Y. \& FIELD, A. (1970) Virus-like particles in serum of patients with Australia-associated-antigen hepatitis. Lancet, i, 848.

Dane, D.S., Cameron, C.H. \& Briggs, M. (1970) Virus-like particles in serum of patients with Australia-associatedantigen hepatitis. Lancet, i, 695.

Drake, M.E., Barondess, J.A., Bashe, W.J., Henle, G., Henle, W., Stokes, J. \& Pennell, R.B. (1953) Failure of convalescent gammaglobulin to protect against homologous serum hepatitis. Journal of the American Medical Association, 152, 690.

Giles, J.P., McCollum, R.W., Berndtson, L.W. \& KrugMAN, S. (1969) Viral hepatitis: Relation of Australia/SH antigen to the Willowbrook MS-2 strain. New England Journal of Medicine, 281, 119.

Krugman, S., Giles, J.P. \& Hammond (1967) Infectious hepatitis: Evidence for two distinctive clinical epidemiological and immunological types of infection. Journal of the American Medical Association, 200, 365.

LEWKONIA, R.M. \& FinN, R. (1969). ABO blood group distribution in serum hepatitis. British Medical Journal, 2, 268.

MacCallum, F.O. (1946) Homologous serum hepatitis. Proceedings of the Royal Society of Medicine, 39, 655.

MacCallum, F.O. (1947) Editorial. Lancet, ii, 692.

MacCallum, F.O. (1953) Hepatitis. British Medical Bulletin, 9, 221.

MacCallum, F.O. \& Bauer, D.J. (1944) Homologous serum jaundice. Transmission experiments with human volunteers. Lancet, i, 622.

Nowoslawski, A., Brzosko, W., Madalinski, K. \& KRAWCZYNSKI, K. (1970) Cellular localisation of Australia antigen in the liver of patients with lymphoproliferative disorders. Lancet, i, 494.

Zuckerman, A.J. \& TAYlor, P.E. (1969) Persistence of the serum hepatitis (SH-Australia) antigen for many years. Nature, 223, 81.

Zuckerman, A.J., TAylor, P.E. \& Bird, R.G. (1970) Review: Antigens and viruses in acute hepatitis. Clinical and Experimental Immunology, 7, 439. 